\title{
METHOD DEVELOPMENT AND VALIDATION FOR THE SIMULTANEOUS DETERMINATION OF STEVIOSIDE, REBAUDIOSIDE-A, REBAUDIOSIDE C AND DULCOSIDE A CONTAINED IN STEVIA REBAUDIANA BERTONI USING HPLC-ELSD
}

\author{
SUPRIYADI ${ }^{1,2}$, SISWANDONO², MOCHAMMAD YUWONO² \\ ${ }^{1}$ Faculty of Pharmacy, Setia Budi University, Indonesia, ${ }^{2}$ Faculty of Pharmacy, Airlangga University, Indonesia \\ Email: Supriusb@gmail.com
}

Received: 24 Feb 2016 Revised and Accepted: 22 Jul 2016

\section{ABSTRACT}

Objective: To develop and validate a selective HPLC-ELSD method for determination of steviol glycosides contained in Stevia rebaudiana, mainly stevioside, rebauside A, rebaudioside $\mathrm{C}$, and dulcoside $\mathrm{A}$.

Methods: The chromatographic separation of stevioside, rebaudioside A, rebaudioside C, and dulcoside A was achieved using Phenomenex Luna column $250 \mathrm{~mm} \times 4.6 \mathrm{~mm}$ i.d. in isocratic system mode with a mobile phase of acetonitrile-water (35: 65). The temperature of nebulization and evaporization of the ELS detector was set at $50^{\circ} \mathrm{C}$ and $70^{\circ} \mathrm{C}$, respectively.

Results: The good separation of stevioside, rebaudioside A, rebaudioside C, and dulcoside A was obtained, yielding the resolution of all the analytes more than 1.5. All the validation parameters like specificity, linearity, range, accuracy and precision met the acceptance criteria according to ICH guidelines.

Conclusion: The proposed HPLC-ELSD method is simple and sensitive for the simultaneously detection and determination of stevioside, rebaudioside A, rebaudioside C and dulcoside A contained in Stevia rebaudiana. The method was successfully applied for the determination of the samples product of Stevia rebaudiana.

Keywords: Stevioside, Rebaudioside A, Rebaudioside C, Dulcoside A, HPLC-ELSD

(C) 2016 The Authors. Published by Innovare Academic Sciences Pvt Ltd. This is an open access article under the CC BY license (http://creativecommons. org/licenses/by/4. 0/) DOI: http://dx.doi.org/10.22159/ijpps.2016.v8i9.11404

\section{INTRODUCTION}

Stevia rebaudiana Bertoni, a medicinal plant in the genus Stevia (family Asteraceae), has become popularly used as a low-calorie sweetener. The use of Stevia rebaudiana leaves as a sugar substitute, especially for diabetics, does not increase blood glucose level and does not cause obesity [1]. The sweet taste of Stevia rebaudiana is obtained from some steviol glycoside chemical compounds, comprising stevioside (4-10\%), rebaudioside A (2-4\%), rebaudioside $C(1-2 \%)$, and dulcoside $A(0.5-1 \%)$; all four are tied to sugar molecules, such as glucose and rhamnose (fig. 1).

Stevia rebaudiana leaves have 30 times sweeter taste than sugar (sucrose) while pure stevioside is 300 times sweeter than sucrose [2].

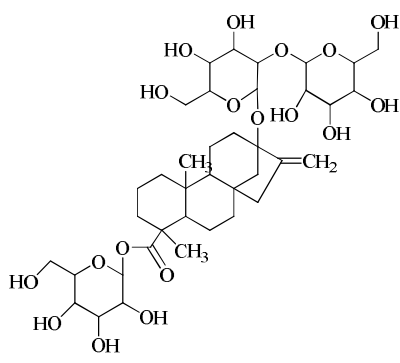

I

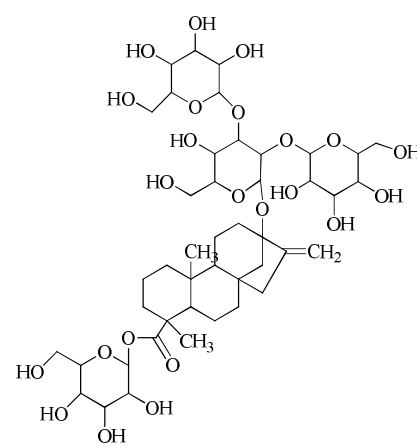

III<smiles>C=C1CC23CCC4C(C)(C(=O)OC5OC(CO)C(O)C(O)C5O)CCCC4(C)C2CCC3(O)C1CC1OC(CO)C(O)C(O)C1OC1OC(C)C(O)C(O)C1O</smiles>

II<smiles>CCC(C)OC1OC(CO)C(O)C(OC2OC(CO)C(O)C(O)C2O)C1OC1OC(C)C(O)C(O)C1O</smiles><smiles>C=C1CC23CCC4C(C)(C(=O)OC5OC(CO)C(O)C(O)C5O)CCCC4(C)C2CC13C</smiles>

IV

Scheme 1: The chemical structure of steviol glycosides (I: Stevioside; II = Rebaudioside A; III = Rebaudioside C and IV = Dulcoside A) 
The acceptable daily intake (ADI) for steviol glycoside of Stevia rebaudiana is $4 \mathrm{mg} / \mathrm{kg}$ body weight/day, and the maximum dosage recommended is 3 and $5 \mathrm{mg} / \mathrm{kg}$ body weight/day in Japan and the USA, respectively [3]. In the aforementioned dosage, Stevia rebaudiana is safe to be consumed as a sweetener to substitute sugar and does not contain calories [4]. According to food and drug administration (FDA) [5], Stevia rebaudiana is a safe and edible product up to a dosage of $1500 \mathrm{mg}$ per day. WHO concluded that stevioside and rebaudioside are not carcinogenic and mutagenic, both in vitro and in vivo assays. Stevioside also gives pharmacological effects on patients as anti-hypertensive and antidiabetic agent [6]. Stevioside and rebaudioside are stable at high temperatures, like other common artificial sweeteners. Both of them are heat-resistant when heated up to $200^{\circ} \mathrm{C}$, and therefore, they can be used nearly almost in all types of food products $[7,8]$.

To assure the quality of commercial sweetener products from Stevia rebaudiana, an analytical method for determination of steviol glycosides in Stevia rebaudiana plays a critical role. In addition, the detection and simultaneous determination of stevioside, rebaudioside $\mathrm{A}$, rebaudioside $\mathrm{C}$ and dulcoside $\mathrm{A}$ become necessary to prevent the adulteration of the stevia products. For such purposes, a number of analytical methods have been described, such as HPTLC $[9,10]$. Capillary Electrophoresis [11] and HPLC [12] and recently LC-MS/MS [13,14]. Shirwaikar et al. identified and estimated stevioside in samples of Stevia rebaudiana by means of HPTLC compared to HPLC methods [15]. HPTLC has also been reported by Saifi et al. for the analysis of stevioside and rebaudioside A in Stevia rebaudiana [16]. The HPTLC is simpler and cheaper, however it generates lower resolution than HPLC. Due to its sensitivity and specificity, HPLC has been therefore most developed for the separation and determination of steviol glycosides in Stevia rebaudiana. Different HPLC columns have been used to separate the steviol glycosides, including amine-based [17], HILIC and reversed phase C-18 phase columns [18].

The HPLC with UV detection at absorption ranging from $200 \mathrm{~nm}$ to $300 \mathrm{~nm}$ has been widely applied for the separation of steviol glycosides. Since stevioside, rebaudioside A, rebaudioside $C$ and dulcoside A are lacking in chromophores, the detection is commonly accomplished at $210 \mathrm{~nm}$ or lower to increase the sensitivity [19]. At this wavelength, the detection is undoubtedly interfered by mobile phase. For this reason, the mobile phase consisting high purity acetonitrile (cut off $190 \mathrm{~nm}$ ) is more favorable than methanol (cut off $210 \mathrm{~nm}$ ). The use of acetonitrile is, however, too expensive for routine analysis.

The evaporative light scattering detector (ELSD) is a valuable HPLC detector for detection of non-UV absorbing compounds, such as stevioside, rebaudioside $\mathrm{A}$, rebaudioside $\mathrm{C}$ and dulcoside $\mathrm{A}$. In the HPLC-ELSD, the compounds of interest are detected by the way it scatters light after nebulization and evaporation in a heated device [20]. The use of HPLC-ELSD for simultaneous determination of stevioside, rebaudioside A, rebaudioside C and dulcoside A in Stevia rebaudiana has not widely described elsewhere.

The objective of the present study was to develop an HPLC-ELSD method for the simultaneously detection and determination of stevioside, rebaudioside A, rebaudioside C and dulcoside A in Stevia rebaudiana. The method was then validated according to ICH Guideline in terms of selectivity, linearity, range, precision, and accuracy as well as limit of detection (LOD) and limit of quantitation (LOQ) [21].

\section{MATERIALS AND METHODS}

\section{Chemicals and instrumentation}

Steviosides, rebaaudioside A, rebaudioside $\mathrm{C}$ and dulcoside $\mathrm{A}$ with purity $>98 \%$ were purchased from Sigma-Aldrich. Methanol and Acetonitrile HPLC grades were obtained from E. Merck (Darmstadt, Germany). Water was procured from PT. Ikapharmindo Putramas, Indonesia. Stevia leaves samples harvested in Tawangmangu, Central java Indonesia. Products used as samples were obtained from Indonesian market.

HPLC separations were carried out on Agilent 1100 Series HPLC equipped with Agilent Technologies 380 ELSD. The HPLC column was Luna Phenomenex 250 x 4.6 mm, ODS3 100A)

\section{Preparation of standard solution}

The standard solution was prepared by dissolving in methanol and transferring it into $10 \mathrm{ml}$ volumetric flask and making up the volume using methanol to obtain the mixed standard solution of stevioside $(430 \mathrm{mg} / \mathrm{l})$, rebaudioside A $(1010 \mathrm{mg} / \mathrm{l})$, rebaudioside C $(1010$ $\mathrm{mg} / \mathrm{l})$ and dulcoside $\mathrm{A}(930 \mathrm{mg} / \mathrm{l})$.

\section{Sample preparation}

Samples of Stevia rebaudiana collected from farmers in October 2015 were oven-dried at $50^{\circ} \mathrm{C}$, powdered and filtered with 20 mesh filter. The powder was later measured to approximately $10 \mathrm{~g}$ and put into $250 \mathrm{ml}$ beaker glass. It was then reconstituted with $100 \mathrm{ml}$ of methanol, heated in hot plate $50 \pm 2{ }^{\circ} \mathrm{C}$, stirred with magnetic stirrers for $15 \mathrm{~min}$, and filtered with filter papers. Much amount of $100 \mathrm{ml}$ of methanol was added to the deposition. Similar processes were repeated 5 times until $500.0 \mathrm{ml}$ of filtrate was extracted and finally ready to analyze by HPLC-ELSD.

\section{Method development}

The HPLC-ELSD method was developed to obtain the best separation of stevioside, rebaudioside $\mathrm{A}$, rebaudioside $\mathrm{C}$ and dulcoside $\mathrm{A}$ simultaneously by injecting the mixed standard solution of stevioside, rebaudioside A, Rebaudioside C and dulcoside An into HPLC-ELSD. Different composition of mobile phase, HPLC columns as well as the temperature of nebulization and evaporation of ELSD were studied.

\section{Method validation}

The quality, reliability and consistency of the developed method were validated according to the ICH guidelines. The characteristic validation parameters include specificity, linearity and range, accuracy, precision, LOD and LOQ with the acceptance criteria of the resolution $\mathrm{R}>1.5$ for specificity; coefficient correlation $\mathrm{R}>0.997$ for linearity; recovery of $98-102 \%$ for accuracy; relative standard deviation $\mathrm{RSD}<2 \%$ for precision; $\mathrm{LOD}=\frac{3.3 \mathrm{SD}}{\mathrm{b}}$ for a limit of detection; and $L O Q=\frac{10 \mathrm{SD}}{\mathrm{b}}$ for limit of quantitation.

\section{RESULTS AND DISCUSSION}

\section{Method development}

Several mobile phases and HPLC columns, as well as the nebulization and the evaporation temperature of ELSD, were initially tried in an attempt to find the best separation for the four steviol glycosides, i.e. rebaudioside A, stevioside, rebaudioside C, and dulcoside A simultaneously. The following HPLC condition was obtained by using Phenomenex Luna column 250 x 4.6 mm i.d., $5 \mu \mathrm{m}$ particle size in isocratic elution with a mobile phase of acetonitrile: water (35: 65). The temperature of nebulization and evaporization of the ELS detector was set at $50^{\circ} \mathrm{C}$ and $70^{\circ} \mathrm{C}$, respectively. The flow rate was $1.0 \mathrm{ml} / \mathrm{min}$. and the volume of injection loop was $20 \mu \mathrm{l}$. Fig. 1 . Shows the typical chromatogram of a mixture of four standard solutions, comprising rebaudioside $\mathrm{A}$, stevioside, rebaudioside $\mathrm{C}$, and dulcoside A, obtained using HPLC-ELSD.

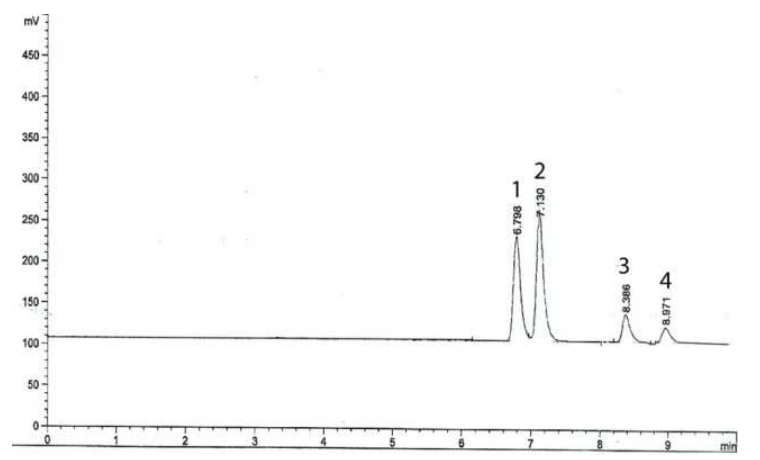

Fig. 1: Chromatogram of standard mixtures by HPLC-ELSD with mobile of acetonitrile: water $35: 65(1=$ rebaudioside $A, 2$ =stevioside, 3 = rebaudioside $C$, and $4=$ dulcoside $A$ ) 


\section{Specificity}

The specificity was tested by comparing the retention time and the resolution of the peaks of stevioside, rebaudioside $A$, rebaudioside $C$ and dulcoside $\mathrm{A}$. The retention time of rebaudioside $\mathrm{A}$, stevioside, rebaudioside $\mathrm{C}$, and dulcoside are $6.70 \mathrm{~min}$., $7.13 \mathrm{~min} ., 8.38 \mathrm{~min}$. and 8.97 min., respectively. The resolution of rebaudioside $A$ and stevioside was 1.89 . The resolution between stevioside and rebaudioside $\mathrm{C}$ was found to be 6.51 and between rebaudioside $\mathrm{C}$ and dulcoside $\mathrm{A}$ was 2.82 . Therefore, the resolution among peaks met the requirements $(\mathrm{R}>1.5)$ for separation according to $\mathrm{ICH}$ Guideline. Injection of other plant extracts used as placebo resulted in no peaks at the retention time of the four steviol glycoside. Fig. 2 presents the typical chromatogram of samples, indicating that the peaks of rebaudioside $\mathrm{A}$, stevioside, rebaudioside $\mathrm{C}$ and dulcoside $\mathrm{A}$ not interfered.

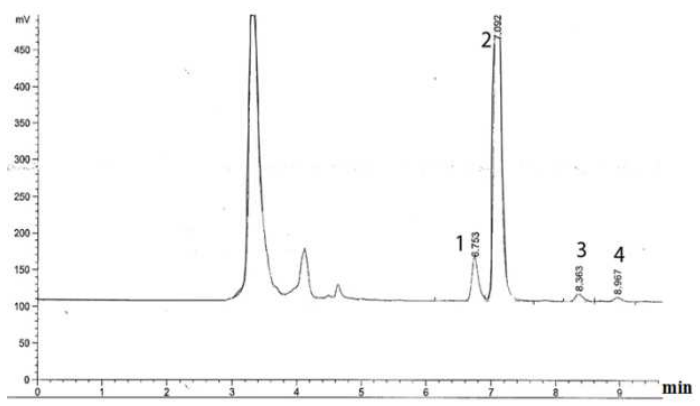

Fig. 2: Chromatogram of extract of Stevia rebaudiana obtained using HPLC-ELSD with mobile of acetonitrile: water 35: 65 (1 = rebaudioside $A, 2$ = stevioside, 3 = rebaudioside $C$, and 4 $=$ dulcoside $\mathrm{A}$ )

\section{Linearity and range}

The calibration with the external standard was performed at five different concentration levels. i.e. between 20.2 and $60.6 \mathrm{mg} / \mathrm{l}$ for rebaudioside A, and between 8.6 and $34.4 \mathrm{mg} / \mathrm{l}$ for stevioside; whilst the concentration levels for rebaudioside $\mathrm{C}$ and Dulcoside $\mathrm{A}$ was ranging from 20.2 to $60.6 \mathrm{mg} / \mathrm{l}$ and from 18.6 to $58.8 \mathrm{mg} / \mathrm{l}$, respectively. The peak area data by their respective concentration levels are summarized in table 1 . The linearity was evaluated by linear least square regression, resulting the linear regression equation $(y=a x+b)$ and the coefficient correlation $(r)$ as shown in fig. 3-6.

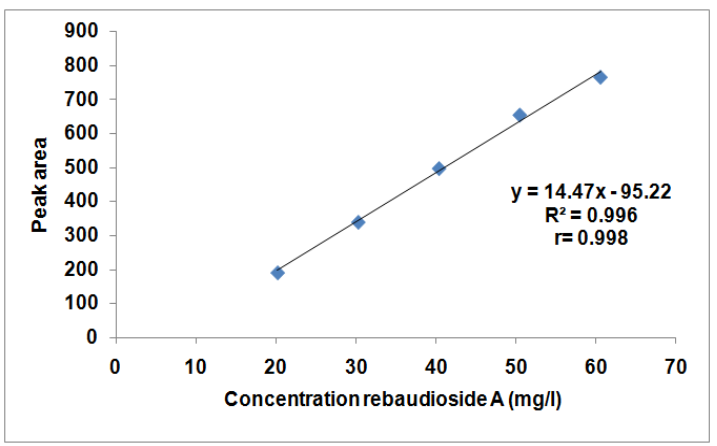

Fig. 3: Linearity of rebaudioside A

\section{LOD and LOQ}

The sensitivity of the method was determined with regard to the limit of detection (LOD) and the limit of quantification (LOQ) by comparing the height of a sample peak and the height of a noise peak. The limit of detection is reached at a signal-to-noise ratio greater than three; the limit of quantification is reached at a signalto-noise ratio greater than ten (ICH 2005). The LOD of the method was found to be $2.98 \mathrm{mg} / \mathrm{l}$ (rebaudioside A), $1.31 \mathrm{mg} / \mathrm{l}$ (stevioside), $2.69 \mathrm{mg} / \mathrm{l}$ (rebaudioside C) and $1.39 \mathrm{mg} / \mathrm{l}$ (dulcoside A). The LOQ of the method for rebaudioside A, Stevioside, rebaudioside and dulcoside A was $9.04 \mathrm{mg} / \mathrm{l}, 3.91 \mathrm{mg} / \mathrm{l}, 8.15 \mathrm{mg} / \mathrm{l}$ and $4.21 \mathrm{mg} / \mathrm{l}$, respectively.

Table 1: Linearity data of rebaudioside a, stevioside, rebaudioside $C$ and dulcoside $A$

\begin{tabular}{|c|c|c|c|c|c|c|c|}
\hline $\begin{array}{l}\text { Rebaudio side } A \\
(\mathrm{mg} / \mathrm{l})\end{array}$ & $\begin{array}{l}\text { Peak area } \\
(\mathrm{mV})\end{array}$ & $\begin{array}{l}\text { Stevio } \\
\text { side } \\
(\mathrm{mg} / \mathrm{l})\end{array}$ & $\begin{array}{l}\text { Peak area } \\
(\mathrm{mV})\end{array}$ & $\begin{array}{l}\text { Rebaudio } \\
\text { side C } \\
(\mathrm{mg} / \mathrm{l})\end{array}$ & $\begin{array}{l}\text { Peak area } \\
(\mathrm{mV})\end{array}$ & $\begin{array}{l}\text { Dulco } \\
\text { side A } \\
\text { (mg/l) }\end{array}$ & $\begin{array}{l}\text { Peak } \\
\text { area } \\
(\mathrm{mV})\end{array}$ \\
\hline 20.2 & 191.38 & 8.6 & 52.79 & 20.2 & 52.8 & 18.6 & 54.29 \\
\hline 30.3 & 339.68 & 17.2 & 132.03 & 30.3 & 95.1 & 27.9 & 94.69 \\
\hline 40.4 & 497.13 & 25.8 & 228.07 & 40.4 & 145.47 & 37.2 & 139.77 \\
\hline 50.5 & 654.07 & 34.4 & 312.85 & 50.5 & 202.53 & 46.5 & 179.25 \\
\hline 60.6 & 765.04 & 43 & 406.64 & 60.6 & 254.34 & 58.8 & 230.09 \\
\hline
\end{tabular}

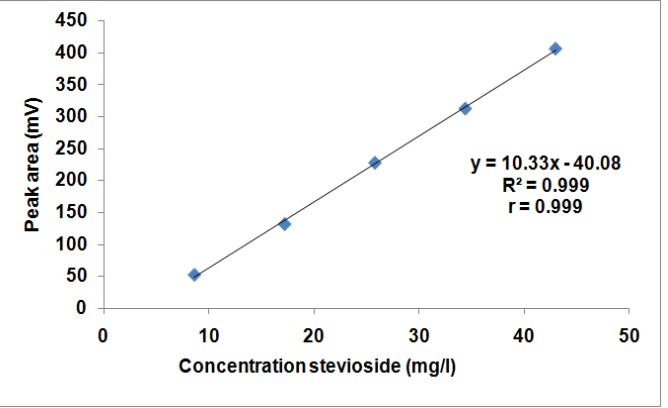

Fig. 4: Linearity of stevioside

\section{Accuracy}

The accuracy of the method was tested by measuring the recovery test of three different concentration levels of standard addition.
Each solution was analyzed in triplicate. The percentage recoveries $\pm \mathrm{SD}$ of rebaudioside $\mathrm{A}$, stevioside, rebaudioside $\mathrm{C}$ and dulcoside A was $101.04 \pm 1.21 \%$; $98.48 \pm 0.42 \%$; $99.95 \pm 0.82 \%$ and $98.97 \pm 1.14 \%$.

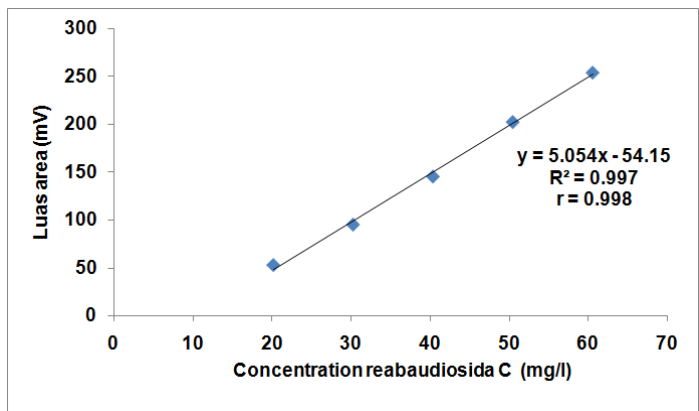

Fig. 5: Linearity of rebaudioside C 


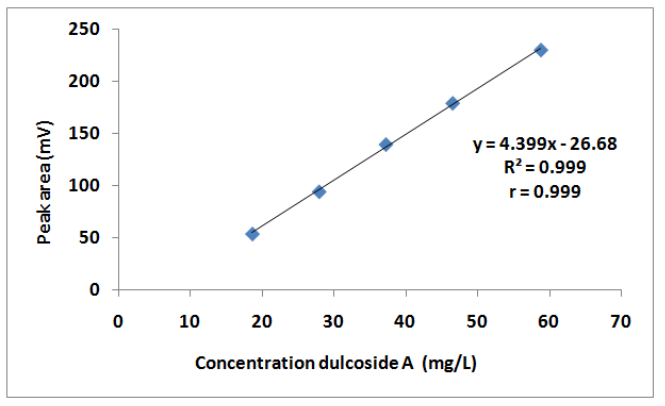

Fig. 6: Linearity of dulcoside A

\section{Precision}

The precision of the method with intra-day precision and inter-day precision were studied. The intra-day precision, also called repeatability, shows the precision of the proposed method under the same operating conditions during a day and is expressed in \% RSD.
The method precision resulted from this study are blow $2 \%$ for all analytes. Table 2 summarized the results of the method validation study.

\section{Sample analysis}

The proposed validated HPLC-ELSD method was applied for detection and quantification of steviol glycosides in samples of Stevia rebaudiana powder. From the retention time of the sample chromatogram, it is concluded that the sample contains stevioside, rebaudioside $\mathrm{A}$, rebaudioside $\mathrm{C}$ and dulcoside $\mathrm{A}$ with concentrations presented in table 3.

The HPLC-ELSD method developed and validated in this study was successfully applied for the analysis of stevioside, rebaudioside A, rebaudioside C and dulcoside A contained in Stevia rebaudiana. The optimum condition was achieved by the use of Phenomenex Luna column $250 \times 4.6 \mathrm{~mm}, 5 \mu \mathrm{m}$ particle size with a mobile phase of acetonitrile: water (35: 65) in the elution of isocratic system. Validation of the method indicated that the method has metal. 1 the acceptance criteria of method validation parameter according to ICH Guidelines: precision $(\mathrm{RSD}<2 \%)$, Correlation coefficient $(\mathrm{r})>0.997$, resolution $(\mathrm{R})>1.5$ ), and percentage (recovery between 98 and $102 \%$.

Table 2: Result of method validation study

\begin{tabular}{|c|c|c|c|c|c|c|c|}
\hline No & $\begin{array}{l}\text { Steviol } \\
\text { glycosides }\end{array}$ & $\begin{array}{l}\text { Resolution } \\
\text { (R) }\end{array}$ & $\begin{array}{l}\text { Correlation coefficient } \\
\text { (r) }\end{array}$ & $\begin{array}{l}\text { LOD } \\
\mathrm{mg} / \mathrm{l}\end{array}$ & $\begin{array}{l}\text { LOQ } \\
\mathrm{mg} / \mathrm{l}\end{array}$ & $\begin{array}{l}\text { Precision RSD } \\
(\%)\end{array}$ & $\begin{array}{l}\text { Accuracy } \\
\text { recovery mean } \pm \text { SD }(\%)\end{array}$ \\
\hline 1 & Rebaudioside $\mathrm{A}$ & - & 0.998 & 2.98 & 9.04 & 0.02 & $101.04 \pm 1.21$ \\
\hline 2 & Stevioside & 1.89 & 0.999 & 1.31 & 3.91 & 0.01 & $98.48 \pm 0.42$ \\
\hline 3 & Rebaudioside C & 6.51 & 0.999 & 2.69 & 8.15 & 0.01 & $99.95 \pm 0.82$ \\
\hline 4 & Dulcoside A & 2.82 & 0.999 & 1.39 & 4.21 & 0.06 & $98.97 \pm 1.14$ \\
\hline
\end{tabular}

Table 3: Concentrations of steviol glycosides in Stevia rebaudiana powder

\begin{tabular}{lll}
\hline S. No. & Names of steviol glycosides & Concentrations mean \pm SD(\%), n=6 \\
\hline 1 & Rebaudioside A & $1.00 \pm 0.01$ \\
2 & Stevioside & $13.95 \pm 0.02$ \\
3 & Rebaudioside C & $0.56 \pm 0.02$ \\
4 & Dulcoside A & $0.50 \pm 0.02$ \\
\hline
\end{tabular}

The results show that the proposed method is specific, accurate and precise as shown by the good recovery and relative standard deviation (RSD) values. Using ELSD as a detector for HPLC in the present work provided advantages for the detection of non-chromophoric compounds, such as stevioside, rebaudioside $\mathrm{A}$, rebaudioside $\mathrm{C}$ and dulcoside A. The utilization of ELSD for HPLC does not depend on either the wavelength of the analytes or UV cut-off the mobile phase solvents. Compared to the results of the study by means of HPLC-UV $[12,15]$, the chromatogram resulted by HPLC-ELSD give the more sensitive and symmetrical peaks with better resolution.

\section{CONCLUSION}

The proposed method of HPLC-ELSD is simple and sensitive for the detection and determination of stevioside, rebaudioside $\mathrm{A}$, rebaudioside C and dulcoside A contained in Stevia rebaudiana. The statistical analysis of the method validation study proves the HPLCELSD method is repeatable, specific and accurate for the analysis Stevia rebaudiana products.

\section{CONFLICT OF INTERESTS}

\section{Declared none}

\section{REFERENCES}

1. Brahmachari G, Mandal LC, Roy R, Mondal S, Arun KB. Stevioside and related compounds-molecules of pharmaceutical promise: a critical overview. Arch Pharm Chem Life Sci 2011;1:5-19.

2. Madan S, Ahmad S, Singh GN, Kohli K, Kumar Y, Singh R, et al. Stevia rebaudiana (Bert.) Bertoni-a review. Indian J Nat Prod Resour 2010;1:267-86.
3. Benford DJ, Dinovi M, Schlatter J. Safety evaluation of certain food a Steviol glycosides WHO food additives series (world health organization joint $\mathrm{FAO} / \mathrm{WHO}$ expert committee on food additives (JECFA); 2006.

4. De S, Mondal S, Banerjee S. Stevioside: technology, applications, and health. John Wiley and Sons; 2013.

5. Benford DJ, Dinovi M, Schlatter J. Steviol glycosides food standards agency, London, United Kingdom, Division of Biotechnology and GRAS notice review office of food additive safety, food and drug administration. College Park: MD USA; 2008.

6. Gardana C, Scaglianti M, Simonetti P. Evaluation of steviol and its glycosides in stevia rebaudiana leaves and commercial sweetener by ultra-high-performance liquid chromatographymass spectrometry. J Chromatogr 2010;2:63-70.

7. Rao AB, Prasad E, Roopa G, Sridhar S, Ravikumar YVL. Simple extraction and membrane purification process in isolation of stevioside with improved organoleptic activity. Adv Biosci Biotechnol 2012;3:327-35.

8. Elnaga NIEA, Massoud MI, Yousef MI, Mohamed HHA. Effect of stevia sweetener consumption as non-caloric sweetening on body weight gain and biochemical's parameters in overweight female rats. Annals of Agric Sci 2015;2:1-9.

9. Morlock GE, Meyera S, Zimmermann B, Roussel JM. Highperformance thin-layer chromatography analysis of steviol glycosides in Stevia formulations and sugar-free food products, and benchmarking with (ultra) high-performance liquid chromatography. J Chromatogr A 2014;1350:102-11.

10. Bergs D, Burghoff B, Joehnck M, Martin G, Schembecker G. Fast and isocratic HPLC-method for steviol glycosides analysis from stevia rebaudiana leaves. J Consum Prot Food Saf 2012;7:147-54. 
11. Mauri P, Catalano G, Gardana C, Pietta P. Analysis of stevia glycosides by capillary electrophoresis. Electrophoresis 1996;17:367-71.

12. Chaturvedula VSP, Zamora J. Reversed-phase HPLC analysis of steviol glycosides isolated from Stevia rebaudiana Bertoni. Food Nutr Sci 2014;5:1711-6.

13. Calle MM, Medina VSD, Torre MPDD, Capote FP, Castro MDLD. Development and application of a quantitative method based on LC-QqQ MS/MS for determination of steviol glycosides in stevia leaves. J Talanta 2016;154:1-27.

14. Adari BR, Alavala S, George SA, Meshram HM, Tiwari AK, Sarma AVS. Synthesis of rebaudioside-A by enzymatic transglycosylation of stevioside present in the leaves of Stevia rebaudiana Bertoni. Food Chem 2016;200:154-8.

15. Shirwaikar A, Parmar V, Bhagat J, Khan S. Identification and estimation of stevioside in the commercial samples of stevia leaf and powder by HPTLC and HPLC. Int J Pharm Life Sci 2011;2:1050-8.

16. Saifi M, Ali1 A, Saini M, Nasrullah N, Khan S, Abdin MZ. A rapid and efficient high-performance thin-layer chromatographic (HPTLC) method for simultaneous analysis of stevioside and rebaudioside-A in stevia rebaudiana. Int J Pharm Pharm Sci 2014;6:455-64.

17. Serfaty M, Ibdah M, Fischer R, Chaimovitsh D, Saranga Y, Dudai N. Dynamics of yield components and stevioside production in stevia rebaudiana grown under different planting times, plant stands, and harvest regime. Ind Crops Prod 2013;50:731-6.

18. Hashimoto Y, Moriyasu M, Nakamura S, Ishiguro S, Komuro M. High-performance liquid chromatographic determination of stevia components on the packed hydrophilic column. J Chromatogr 1978;161:403-5.

19. Purkayastha S, Markosyan A, Prakash I, Bhusari S, Pugh Jr G, Lynch B, et al. Steviol glycosides in purified stevia leaf extract sharing the same metabolic fate. Regul Toxicol Pharmacol 2016;77:125-33.

20. Lucena RS, Cardenas, Valcarcel M. Evaporative light scattering detection: trends in its analytical uses. Anal Bioanal Chem 2007;388:1663-72.

21. ICH Harmonized Tripartite Guidelines on Validation of Analytical procedures: Text and Methodology Q2 (R1). Current step 4 version: Geneva; 2005.

\section{How to cite this article}

- Supriyadi, Siswandono, Mochammad Yuwono. Method development and validation for the simultaneous determination of stevioside, rebaudioside a, rebaudioside $\mathrm{c}$ and dulcoside a contained in Stevia rebaudiana bertoni using HPLCELSD. Int J Pharm Pharm Sci 2016;8(9):1-5. 